\title{
Asyndromic isolated unilateral Tessier cleft 8 with euryblepharon
}

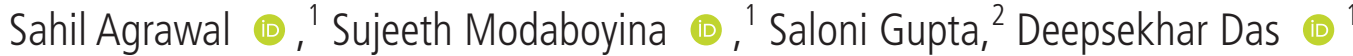

${ }^{1}$ Ophthalmology, Dr Rajendra Prasad Centre for Ophthalmic Sciences, AllMS, Delhi, India ${ }^{2}$ Ophthalmology, Northern Railway Central Hospital, New Delhi, India

\section{Correspondence to} Dr Deepsekhar Das: doc.deep.das@gmail.com

Accepted 7 October 2021

\section{DESCRIPTION}

Tessier developmental cleft anomalies are exceedingly rare conditions. The nature and extent of the anomaly vary according to the cleft number. ${ }^{1}$ Although the exact incidence is unclear, it is estimated between 1.4 and 4.9 per 100000 live births. ${ }^{2}$

A 13-year-old female patient presented to an ophthalmology outpatient department with problems of a large palpebral aperture on the left side along with watering and foreign body sensation. Her parents stated that the ocular deformity had been there since birth. On general examination, the patient was alert, conscious and cooperative with stable vitals. There was obvious left-sided malar hypoplasia (figure 1A).

On ocular adnexal examination, there was a lateral coloboma of the left eyebrow along with the inward rotation of the lateral half of the upper eyelid with a coloboma. The lateral canthus was dystopic, with a bunch of eyelashes located on top of it (figure 1B). There was a left-sided euryblepharon as the horizontal aperture of the left side was $34 \mathrm{~mm}$, whereas, on the right side, it was $29 \mathrm{~mm}$. The lower eyelid appeared stretched with mild ectropion, and a prominent lacus lacrimalis lateralis was noted. The lateral bulbar conjunctiva also had

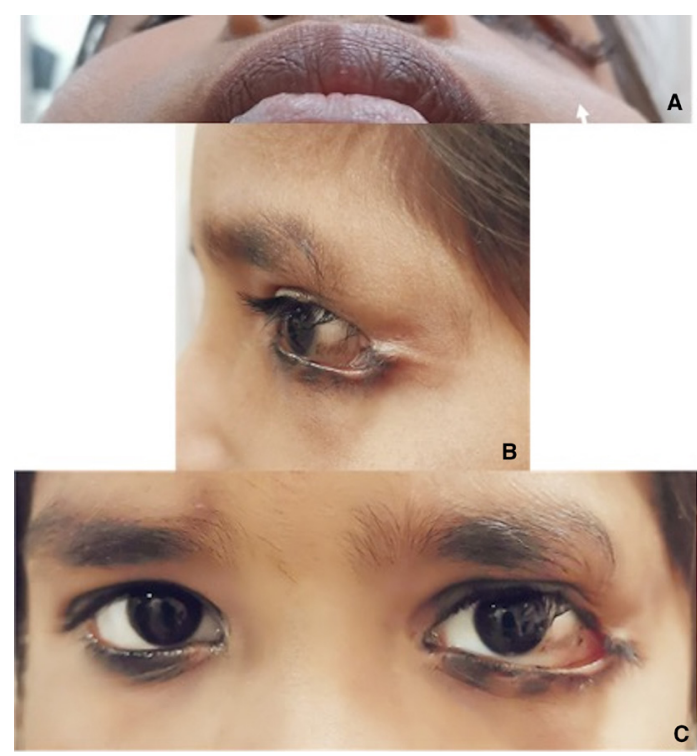

Figure 1 (A) Clinical picture of the patient showing left-sided malar hypoplasia. (B and C) Clinical picture of the patient showing left euryblepharon, eyebrow madarosis, upper eyelid coloboma with entropion, lateral canthal dystopia with an elevation(B), stretched lower eyelid margin, lower eyelid ectropion with lacus lacrimalis lateralis and temporal bulbar conjunctival keratinisation. evidence of keratinisation (figure 1C). The ocular adnexa on the right side and rest of the anterior and posterior segments of either eye was within normal limits with visual acuity of 6/6 on Snellen's chart.

Based on the clinical features, a diagnosis of Tessier cleft number 8 with euryblepharon was made. The patient underwent lateral canthoplasty (the lateral canthal angle was opened and the lateral eyelid reanchored to the periosteum of the lateral orbital rim using 6-0 prolene sutures) along with upper lid coloboma repair and had a cosmetically favourable outcome.

Tessier classified congenital craniofacial clefts based on their anatomical position by giving them numbers from 0 to $14 .^{13}$ They can be further subdivided into the midline, paramedian, orbital and lateral clefts. ${ }^{4}$ The lateral clefts are in a horizontal plane with respect to the face, and they include numbers from 6 to $8 .^{1}$ The lateral clefts are characteristically associated with some syndromes, likely Treacher Collin and Goldenhar syndrome. In Treacher Collins syndrome, clefts number 6, 7 and 8 occur in various combinations; however, Goldenhar syndrome is associated with cleft number $8 .{ }^{5}$ Tessier cleft 8 involves both bone and soft tissue and extends from the lateral canthus to the temporal region and often, a bone cleft along the frontozygomatic suture is associated with it. The lateral canthus in cleft 8 characteristically has an elevation that breaks the continuity of the orbicularis muscle leading to malfunctioning of the orbicularis muscle and other structures attached to the lateral canthus. ${ }^{1}$

Our patient had an elevation located at the lateral canthus with a patch of eyelashes on top. She had no other syndromic features to diagnose as Goldenhar or Treacher collin syndrome. The surgical corrections described for cleft 8 involves the use of cleft skin and local flaps. ${ }^{6}$ Few authors have described

\section{Patient's perspective}

We have been told that our child has a uncommon anomaly and are glad that has been taken care of.

\section{Learning points}

Asyndromic isolated unilateral Tessier cleft 8 with euryblepharon is an extremely rare entity, and this is the first known documented case from the Indian subcontinent.

- A lateral canthoplasty with repair of coloboma provides satisfactory outcome in such cases. 
the surgical resection of dermolipoma and suturing the abnormal fibrous tissue and muscles to the periosteum of the lateral orbital rim. ${ }^{4}$ In our case, we were able to obtain a satisfactory cosmetic outcome by employing lateral canthoplasty along with upper eyelid coloboma repair.

Contributors SA is the primary point of contact and operating surgeon. SM did final review of the manuscript. SG helped in drafting the manuscript. DD acts as a guarantor and operating surgeon.

Funding The authors have not declared a specific grant for this research from any funding agency in the public, commercial or not-for-profit sectors.

Competing interests None declared.

Patient consent for publication Consent obtained from parent(s)/guardian(s)

Provenance and peer review Not commissioned; externally peer reviewed.

\section{ORCID iDs}

Sahil Agrawal http://orcid.org/0000-0001-6667-249X

Sujeeth Modaboyina http://orcid.org/0000-0002-1306-5722

Deepsekhar Das http://orcid.org/0000-0002-4446-0274

\section{REFERENCES}

1 Tessier P. Anatomical classification facial, cranio-facial and latero-facial clefts. J Maxillofac Surg 1976;4:69-92.

2 Kalantar-Hormozi A, Abbaszadeh-Kasbi A, Goravanchi F, et al. Prevalence of rare craniofacial clefts. J Craniofac Surg 2017;28:e467-70.

3 Das D, Rathod A, Gupta S, et al. Isolated unilateral Tessier cleft 10 with anterior staphyloma. Korean J Ophthalmol 2021;35:244-5.

4 Lessa S, Sebastiá R, Pontello J. Lateral Canthal clefts of the eyelid. Ophthalmic Plast Reconstr Surg 2019;35:491-4.

5 Jaworska M, Dudkiewicz Z. Goldenhar's syndrome, typical and atypical forms. Report of two cases. Acta Chir Plast 1974;16:78-84.

6 Fuente-del-Campo A. Surgical correction of Tessier number 8 cleft. Plast Reconstr Surg 1990;86:658-61

Copyright 2021 BMJ Publishing Group. All rights reserved. For permission to reuse any of this content visit

https://www.bmj.com/company/products-services/rights-and-licensing/permissions/

BMJ Case Report Fellows may re-use this article for personal use and teaching without any further permission.

Become a Fellow of BMJ Case Reports today and you can:

- Submit as many cases as you like

- Enjoy fast sympathetic peer review and rapid publication of accepted articles

- Access all the published articles

Re-use any of the published material for personal use and teaching without further permission

\section{Customer Service}

If you have any further queries about your subscription, please contact our customer services team on +44 (0) 2071111105 or via email at support@bmj.com.

Visit casereports.bmj.com for more articles like this and to become a Fellow 